DOI: $10.21802 / \operatorname{artm} .2019 .3 .11 .13$.

УДК $616.007 .61+616.12+616.12-008.46+616.127-005.8+615.03$

\title{
ДИНАМІКА ПОКАЗНИКІВ ГІПЕРТРОФІЇ ТА РЕМОДЕЛЮВАННЯ ЛІВОГО ШЛУНОЧКА У ХВОРИХ $З$ ДЕКОМПЕНСОВАНОЮ СЕРЦЕВОЮ НЕДОСТАТНІСТЮ В ПОСТІНФАРКТНОМУ ПЕРІОДІ ПІСЛЯ ПРОВЕДЕНОГО ВІДНОВНОГО ЛІКУВАННЯ
}

\author{
І.П. Вакалюк, Х.В. Левандовська
}

Івано-Франківський національний медичний університет, кафедра внутріиньої медицини №2 та медсестринства, м. Івано-Франківськ, Україна, ORCID ID: 0000-0002-4430-6816, ORCID ID: 0000-0003-3259-7940, e-mail: levandovska87@ukr.net

Резюме. Ціль: визначити основні показники гіпертрофії та ремоделювання лівого шлуночка у хворих після перенесеного інфаркту міокарда, ускладненого декомпенсованою серцевою недостатністю, та динаміку їх змін на фоні проведеного лікування янтарною кислотою та препаратами аргініну.

Матеріали і методи дослідження. Обстежено 120 хворих із діагнозом Q-QS та не-Q інфаркт міокарда, в яких зафіксована декомпенсована ХCH II А-Б стадії за класифікацією В. Х. Василенка та М. Д. Стражеска IIIIV ФК (за NYHA). Досліджені групи були однорідними за віком, статтю, важкістю перебігу захворювання, тривалістю постінфарктного періоду, наявністю клінічних проявів декомпенсації. Всім пацієнтам проведено ехокардіографічне обстеження на апараті «CARIS PLUS» («Biomedice», Італія). Були оцінені показники ремоделювання та гіпертрофії міокарда.

Результати дослідження та їх обговорення. Протягом 2 місяців лікування хворих із перенесеним Q IM було констатоване значне покращення гемодинамічних показників функціонування ЛШ та його скоротливої функції. Такі показники, як КДО, КСО, КДР, КСР, ММЛШ та ІММЛШ значно знизились у всіх обстежених пацієнтів, а особливо у тих, які поряд зі стандартною терапією отримували комбінацію препаратів янтарної кислоти та аргініну. При аналізі показників Ехо КГ у хворих із перенесеним не-Q IM, ускладненим декомпенсованою СН, встановлено достовірне зниження метричних та об’ємних показників ЛШ через 1 та 2 місяці лікування.

Висновки. Застосування у хворих після перенесеного IM, ускладненого декомпенсованою СH, янтарної кислоти та препаратів аргініну дозволяє забезпечити покращення метричних та об'ємних показників серця, а також, певною мірою, стримати первинне та вторинне ремоделювання ЛШ. Саме тому застосування поряд 3 базовою терапією цих препаратів є доцільним для такого контингенту хворих.

Ключові слова: ремоделювання міокарда, декомпенсована серцева недостатність, інфаркт міокарда, янтарна кислота, препарати аргініну.

Вступ. Серцево-судинні захворювання (СС3), особливо СН та IM, вражають більше $20 \%$ людської популяції віком понад 40 років. Попри те, що клінічні настанови щодо них давно затверджені, рівень смертності з приводу СН та іiі декомпенсації перевищує $50 \%$ протягом 5 років після вперше поставленого діагнозу, що робить СН провідною причиною захворюваності та смертності в усіх індустріальних країнах [10]. Важливим компонентом ланцюга подій, які ведуть до розвитку $\mathrm{CH}$ та iï декомпенсації, $є$ гіпертрофія та дисфункція ЛШ, його насосна недостатність [9]. До цієї когорти можна віднести і нейрогуморальну дисфункцію, ремоделювання міокарда та структурні зміни серця [13]. СН із зниженою систолічною функцією ЛШ характеризується шлуночковою дилатацією та збільшенням саркомеру в кардіоміоцитах [8].

Ремоделювання серця, як відповідь до змін та реорганізація нормальної структури серця та судин, $є$ хронічним неадаптивним процесом, який характеризується прогресуванням міокардіальної гіпертрофії, апоптозу, шлуночкової дилатації, фіброзу, судинної дисфункції [14]. Це стан, який може відноситись як до фізіологічних, так і до патологічних процесів організму. Фізіологічне ремоделювання може розвиватись у відповідь на ріст, постійне фізичне навантаження, вагітність і характеризується запуском витончених та організованих адаптативних механізмів. Патологічне, у свою чергу, розвивається в умовах запалення, ішемії, травми, біомеханічного стресу, як відповідь на надлишкову нейрогуморальну активацію та надмірне постнавантаження, є процесом структурних та функціональних змін лівого шлуночка у відповідь на внутрішнє чи зовнішнє серцево-судинне ураження, і є попередником клінічної СН [17]. Серцеве запалення, що виникає після перенесеного IM, $\epsilon$ основною рушійною силою відтермінованої регенерації кардіоміоцитів. Продукція клітин позаклітинного матриксу є необхідною для забезпечення механічної підтримки процесів регенерації. Однак, динамічні зміни, які відбуваються в позаклітинному матриксі, змушують тканини серця до сповільненого віднов- 
лення, тривалої запальної реакції та втрати кардіоміоцитів [12]. Вцілілі кардіоміоцити зазнають ексцентричної гіпертрофії - процесу, який характеризується подовженням клітини зі зменшенням діаметру та порушенням обміну кальцію [12]. Ці внутрішньоклітинні зміни є фундаментальними для розвитку ремоделювання, яке маніфестує, як стоншення стінки ЛШ, дилатації та зниження його скоротливої функції [6].

Вимірювання фракції викиду ЛШ, маси міокарда та індексу маси міокарда є вагомими ознаками проведеного лікування як при СН, так і при ії декомпенсації [15]. Наукові дослідження свідчать про прямий зв'язок між ознаками ремоделювання ЛШ та покращенням результатів лікування таких пацієнтів у вигляді зворотного ремоделювання [16].

Додатковим напрямком в лікуванні декомпенсованої СН в ранньому та пізньому постінфарктному періоді являється цито- та мембранопротекція, в основі якої лежить застосування гемодинамічно нейтральних препаратів, які є енергетичним субстратом та володіють властивостями утворення та зберігання макроергічних сполучень в кардіоміоцитах [2]. Оскільки нейрогуморальний дисбаланс є одним із ключових механізмів розвитку $\mathrm{CH}$, цілком виправданим $\epsilon$ застосування препаратів аргініну, до складу яких входить оксид азоту, який перешкоджає проліферації гладком'язових клітин стінки судин [4].

Янтарна кислота (ЯК) - сполука, яка стимулює утилізацію жирних кислот, має позитивний вплив на процеси енергозабезпечення кардіоміоцитів. ЯК являється внутрішньоклітинним метаболітом, який широко бере участь у обмінних процесах організму, зменшує ознаки гіпоксії шляхом зниження концентрації пірувату, лактату та цитрату [4]. Важливим напрямком дії препаратів ЯК $є$ відновлення біомеханічних процесів, покращення енергозабезпечення та обмінних процесів пошкодженого кардіоміоцита, а, головне, підвищення адаптативних можливостей як організму, так і клітини зокрема [3], що дозволяє безпосередньо впливати на складні механізми формування ремоделювання ЛШ в постінфарктному періоді, ускладненому декомпенсованою СН.

Оскільки ендотеліальна дисфункція є одним iз ключових механізмів розвитку та прогресування $\mathrm{XCH}$, застосування препартів L-аргініну є виправданим, бо така терапія зменшує дефіцит оксиду азоту (NO), що, своєю чергою, покращує стан ендотелію судин [1].

Обгрунтування дослідження: Оскільки лівошлуночкова гіпертрофія та ремоделювання $\epsilon$ ваговим фактором розвитку СН в постінфарктному періоді і являється предиктором смертності внаслідок їі декомпенсації [11], тому пошук лікарських засобів для їх корекції $є$ необхідним. Постінфарктне ремоделювання $є$ однією із найважливіших змін архітектури серця, що викликає гемодинамічний дисбаланс під впливом патологічних стимулів та біомеханічного стресу. Сам процес ремоделювання включає патологічні зміни структури, форми, розміру, маси та функції серця та його клітин [6]. Водночас, процеси відновлення та ремоделювання серця, навіть у схожих клінічних ситуаціях, при рівних умовах, таких як розмір інфарктної зони, місце розташування, період розгорнутої клінічної картини до лікування та сама стратегія терапії, вік пацієнтів, відбуваються по різному [7]. Так, запобігання та регрес серцевого ремоделювання $\epsilon$ ключовою стратегією лікування $\mathrm{CH}$ та іiі декомпенсації в постінфарктному періоді [14].

Мета роботи: оскільки постінфарктне ремоделювання лівого шлуночка $є$ важливим маркером поліпшення результатів лікування пацієнтів в умовах прогресування $\mathrm{CH}$, ми прагнули дослідити вплив янтарної кислоти та препаратів аргініну на ехокардіографічні показники цього патологічного стану.

Матеріали та методи: Обстежено 120 хворих із діагнозом Q-QS та не-Q інфаркт міокарда, в яких зафіксована декомпенсована ХCH II А-Б стадії за класифікацією В. Х. Василенка та М. Д. Стражеска III-IV ФК (за NYHA). Хворі $з$ діагнозом Q-QS інфаркт міокарда (60 пацієнтів) були сформовані у 4 групи залежно від отриманих методів лікування: 1. 15 хворих, які отримували базову терапію, відповідно до протоколів МO3 України (лізиноприл 10 мг 1 раз на добу; бісопрололу фумарат 10 мг 1 раз на добу; еплеренон 50 мг 1 раз на добу; валсартан 40 мг 2 рази на добу; івабрадин 5 мг 2 рази на добу); 2. 15 хворих, які на фоні базової терапії отримували препарат янтарної кислоти за запропонованою схемою; 3. 15 хворих, які на фоні базової терапії отримували препарати аргініну за запропонованою схемою; 4. 15 хворих, які на фоні базової терапії отримували янтарну кислоту та препарати аргініну за запропонованою схемою. Аналогічно були сформовані у 4 групи пацієнти 3 діагнозом не-Q IM (60 пацієнтів). Тівортін (аргініну гідрохлорид фірми «Юрія-Фарм», Україна, Київ) затверджений Наказом МО3 від 18.09.2008 р. № 528, реєстраційний номер UA/8954/01/01. Препарат призначали по 100 мл 4,5\% розчину 1 раз на добу внутрішньовенно крапельно зі швидкістю 10 крапель за хвилину за перші 10-15 хвилин, потім швидкість введення збільшували до 30 крапель на хвилину (протягом перших 10 днів). Тівортін Аспартат (L-аргініну аспартат, кислота аспарагінова фірми «Юрія-Фарм», Україна, Київ) затверджений Наказом МO3 від 18.08.2009 р., реєстраційний номер UA/9941/01/01. Препарат призначали внутрішньо, під час прийому їжі по 5 мл 5 разів на добу, максимальна добова доза $=8$ г (з 11 дня рандомізації, тривалість 15 днів). Мексикор (3-гідрокси-6-метил-2-етилпіридину сукцинат, розчин для ін'єкцій, ТОВ «Екофармінвест», Російська федерація) затверджений Наказом МO3 від 18.08.2006 р., реєстраційний номер UA/4971/01/01. Препарат призначали внутрішньовенно, шляхом краплинної інфузії, повільно, на фізіологічному розчині або 5\% розчині декстрози (глюкози), в об'ємі 100-150 мл, протягом 30-90 хвилин, 3 рази на добу, кожні 8 годин, протягом перших 10 днів. Добова терапевтична доза $=6-9$ мг/кг, разова доза $=2$ мг/кг маси тіла. Максимальна добова доза не повинна перевищувати 800 мг, разова = 250 мг. Мексикор (етилметилгідроксипіридину сукцинат, капсули, виробник ТОВ «Екофармінвест», Російська федерація) затверджений Наказом МО3 від 06.03.2015 р., реєстраційний номер UA/4971/02/01. Препарат призначали внутрішньо в дозі 100 мг 3 рази на добу після 10 дня госпіталізації, протягом 5 місяців. Максимальна терапевтична доза 
$=800$ мг, разова $=200$ мг. Добову дозу препарату розподіляли на 3 прийоми упродовж дня. Хворі спостерігались на 1 день після госпіталізації та протягом 1, 2 місяця після проведеного лікування амбулаторно.

Досліджені групи були однорідними за віком, статтю, важкістю перебігу захворювання, тривалістю постінфарктного періоду, наявністю клінічних проявів декомпенсації, що стало основою для включення осіб в дослідження.

Були оцінені показники ремоделювання (зміни в часі архітектоніки і функції шлуночків із експансією сполучної тканини за умов активованого нейрогуморального фону внаслідок постінфарктного кардіосклерозу, «приголомшеного» (stunned) міокарда, «сплячого» (hybernating) міокарда та транзиторної ішеміi), кінцево-діастолічний розмір (КДР) ЛШ, кінцево-діастолічний об'єм (КДО) ЛШ, товщина міжшлуночкової перегородки (ТМШП) в систолу та діастолу, товщина задньої стінки ЛШ (ТЗСЛШ) під час систоли та діастоли серця, маса міокарда (ММЛШ), індекс маси міокарда (IММЛШ) та показник «стінкарадіус» усіх обстежуваних хворих.

Також була оцінена фракція викиду ЛШ (ФВ ЛШ) в процентах за Simpson, оскільки згідно 3 рекомендаціями Американської асоціації кардіологів і Американської асоціації серця визначення ФВ після ГІМ має показання I класу з рівнем доказів В. Так, ФВ ЛШ від $40 \%$ до $49 \%$ розцінювалась, як проміжний рівень дисфункції ЛШ, вище 50\% - збережена функція ЛШ та ФВ нижче $40 \%$ - знижена систолічна функція ЛШ.

Статистична обробка отриманих результатів проводилась із допомогою комп'ютерної програми STATISTICA-7 та пакета статистичних функцій програми «Microsoft-Excel» на персональному комп'ютері, із застосуванням варіаційностатистичного методу аналізу. В ході роботи було вирахувано середнє арифметичне М, середнє квадратичне відхилення $\delta$, середню помилку середньої арифметичної m, число варіанта (n), вірогідність різниці двох середньоарифметичних «р», величини $\mathrm{p}<0,05$ оцінювали вірогідними.

Результати та обговорення. Протягом 2 місяців лікування хворих із перенесеним Q IM було констатоване значне покращення метричних та об'ємних показників ЛШ та його скоротливості (табл. 1). Відповідно до даних Ехо КГ, як через 1, так і через 2 місяці спостереження, у всіх групах хворих констатовано достовірне $(\mathrm{p}<0,05)$ зниження КДО та КСО. Так, КДО у хворих, які отримували стандартну терапію до лікування, становив $(240,47 \pm 4,97)$ мл, через 1 місяць - $(203,80 \pm 4,28)$ мл $(\mathrm{p}<0,05)$. У групі хворих, лікованих янтарною кислотою, КДО становив $(240,33 \pm 7,09)$ мл, $(189,53 \pm 4,37)$ мл, $(175,20 \pm 4,46)$ мл $(\mathrm{p}<0,05)$ відповідно, у групі хворих, лікованих препаратами аргініну - $(240,93 \pm 5,32)$ мЛ, $(197,80 \pm 4,06)$ мЛ, $(180,0 \pm 4,51)$ мЛ ( $<<0,05)$ відповідно та при поєднаному застосуванні янтарної кислоти та препаратів аргініну $(240,07 \pm 5,20)$ мл, $(181,93 \pm 5,60)$ мл, $(175,80 \pm 3,93)$ мл $(\mathrm{p}<0,05)$ відповідно. Показник КСО знизився від $(146,6 \pm 3,29)$ мл до $(108,93 \pm 3,59)$ мл $(\mathrm{p}<0,05)$ при ста- ндартній терапії; від $(148,73 \pm 2,96)$ мл до $(92,67 \pm 2,38)$ мл $(\mathrm{p}<0,05)$ при використанні янтарної кислоти; від $(146,13 \pm 3,09)$ мл до $(100,80 \pm 4,99)$ мл $(\mathrm{p}<0,05)$ при використанні препаратів аргініну та від $(149,27 \pm 3,13)$ мл до $(81,80 \pm 4,14)$ мл $(\mathrm{p}<0,05)$ при поєднанні запропонованих препаратів. Неоднозначними були зміни ММЛШ та ІММЛШ. Так, ММЛШ у групі хворих, які отримували стандартну терапію, склав $(416,67 \pm 3,98)$ г до лікування, $(315,20 \pm 3,78)$ г після 1 місяця лікування, $(278,07 \pm 3,88)$ г $(\mathrm{p}<0,05) 2$ місяця після лікування, у групі хворих, які отримували янтарну кислоту цей показник склав $(414,07 \pm 3,51)$ г до лікування, $(259,33 \pm 2,58) \quad$ г після 1 місяця лікування та $(229,53 \pm 4,31)$ г $(\mathrm{p}<0,05)$ після 2 місяців лікування. У групі хворих, що отримували препарати аргініну, цей показник склав $(413,33 \pm 3,27)$ г, $(280,87 \pm 3,23)$ г, $(249,73 \pm 3,15)$ г $(\mathrm{p}<0,05)$ відповідно та у групі хворих, де поряд із стандартним лікуванням застосовували янтарну кислоту та препарати аргініну $(414,53 \pm 2,95) \Gamma$, $(255,27 \pm 2,71)$ г, $(224,60 \pm 3,29)$ г $(\mathrm{p}<0,05)$ відповідно. Констатовано достовірне збільшення ФВ у всіх групах хворих, а особливо у групі, де поряд із стандартною терапією застосовували янтарну кислоту та препарати аргініну. Так, якщо у групі хворих, де використовували стандартну терапію цей показник підвищився від $(39,60 \pm 1,72) \%(p<0,05)$ після 2 місяців лікування, то у четвертій групі хворих ФВ збільшилась від $(40,00 \pm 1,60) \%$ до $(53,07 \pm 1,75) \%(p<0,05)$ відповідно. Показник «стінка-радіус» при використанні стандартної терапії становив $(0,36 \pm 0,02)$ у.од. до лікування, $(0,35 \pm 0,02)$ у.од. $(\mathrm{p}<0,05)$ після 1 місяця лікування та $(0,32 \pm 0,05)$ у.од. $(\mathrm{p}<0,05)$ після 2 місяців лікування; при застосуванні янтарної кислоти: $(0,35 \pm 0,03) \quad$ у.од., $\quad(0,31 \pm 0,02) \quad$ у.од. $\quad(p<0,05)$, $(0,32 \pm 0,02)$ у.од. $(\mathrm{p}<0,05)$; при застосування препаратів аргініну: $(0,36 \pm 0,02)$ у.од., $(0,38 \pm 0,02)$ у.од., $(\mathrm{p}<0,05),(0,31 \pm 0,03)$ у.од. $(\mathrm{p}<0,05)$ та при поєднанні янтарної кислоти, препаратів аргініну: $(0,36 \pm 0,02)$ у.од., $(0,35 \pm 0,03)$ у.од. $\quad(\mathrm{p}<0,05), \quad(0,33 \pm 0,03)$ у.од. $(\mathrm{p}<0,05)$ відповідно.

При аналізі показників Ехо КГ у хворих із перенесеним не-Q IM встановлено достовірне зниження КДР та КСР через 1 та 2 місяці лікування (табл. 2). КДР при використанні стандартної терапії знизився від $(6,89 \pm 0,19) \quad$ см до лікування до $(6,07 \pm 0,23)$ см $(p<0,05)$ після 2 місяців терапії, при використанні янтарної кислоти - від $(6,71 \pm 0,21)$ см до $(5,88 \pm 0,21)$ см $(\mathrm{p}<0,05)$ відповідно, при використанні препаратів аргініну від $(6,66 \pm 0,17) \mathrm{cm}$ до $(6,03 \pm 0,07)$ см $(\mathrm{p}<0,05)$ та при поєднаному застосуванні препаратів від $(6,65 \pm 0,11)$ см до $(5,69 \pm 0,09)$ см $(\mathrm{p}<0,05)$ відповідно. КСР у першій групі до лікування склав $(5,59 \pm 0,16)$ см та $(4,81 \pm 0,13)$ см $(\mathrm{p}<0,05)$ після 2 місяців терапії, у другій групі - $(5,49 \pm 0,11)$ см та $(4,41 \pm 0,15)$ см $(\mathrm{p}<0,05)$ відповідно, у третій групі $(5,49 \pm 0,12)$ см та $(4,58 \pm 0,40)$ см $(\mathrm{p}<0,05)$ відповідно та у четвертій групі - $(5,51 \pm 0,13))$ см та $(4,19 \pm 0,19)$ см $(\mathrm{p}<0,05)$. Також зазнали змін і показники ТЗСЛШ i ТМШП. 
Таблиця 1

Динаміка показників гемодинаміка у хворих $з$ перенесеним Q інфарктом міокарда та декомпенсованою серцевою недостатністю

\begin{tabular}{|c|c|c|c|c|c|c|c|c|c|c|c|c|}
\hline \multirow{2}{*}{ Група/ } & \multicolumn{3}{|c|}{ Стандартне лікування (n=15) } & \multicolumn{3}{|c|}{$\begin{array}{c}\text { Стандартне лікування + } \\
\text { янтарна кислота }(\mathrm{n}=15)\end{array}$} & \multicolumn{3}{|c|}{\begin{tabular}{|c|} 
Стандартне лікування + \\
препарати аргініну $(\mathrm{n}=15)$
\end{tabular}} & \multicolumn{3}{|c|}{$\begin{array}{c}\text { Стандартне лікування + } \\
\text { янтарна кислота } \\
+ \text { препарати аргініну }(\mathrm{n}=15)\end{array}$} \\
\hline & $\begin{aligned} \text { До ліку } \\
\text { вання }\end{aligned}$ & $1 \mathrm{Mi}$ & Mic. & \begin{tabular}{|c|} 
До ліку- \\
вання
\end{tabular} & $1 \mathrm{M}$ & 2 мic. & \begin{tabular}{|c|} 
До ліку- \\
вання
\end{tabular} & 1 міс. & 2 mic. & \begin{tabular}{|c|} 
До ліку- \\
вання
\end{tabular} & Mic & 2 мic. \\
\hline КДО, & $\begin{array}{c}240,47 \pm \\
4,97\end{array}$ & $\begin{array}{c}4,28 \\
\mathrm{p} 1 * \\
\Delta-15,24\end{array}$ & $\begin{array}{c}189,13 \pm \\
4,69 \\
\mathrm{p}^{*}, \mathrm{p} 2 * \\
\Delta-21,35\end{array}$ & $\begin{array}{c}240,33 \pm \\
7,09\end{array}$ & $\begin{array}{c}4,37 \\
\mathrm{p} 1^{*} \\
\Delta-21,14\end{array}$ & $\begin{array}{c}175,20 \pm \\
4,46 \\
\mathrm{p} 1^{*}, \mathrm{p} 2 * \\
\Delta-27,10\end{array}$ & $\begin{array}{c}240,93 \pm \\
5,32\end{array}$ & $\begin{array}{c}197,80 \pm \\
4,06 \\
\mathrm{p} 1 * \\
\Delta-17,90 \\
\end{array}$ & $\begin{array}{c}180,0 \pm \\
4,51 \\
\mathrm{p} 1 *, \mathrm{p} 2 * \\
\Delta-25,29\end{array}$ & \begin{tabular}{|c|}
$240,07 \pm$ \\
5,20
\end{tabular} & $\begin{array}{c}5,60 \\
\mathrm{p} 1 * \\
\Delta-24,21\end{array}$ & $\begin{array}{c}3,93 \\
\mathrm{p} 1^{*}, \mathrm{p} 2 * \\
\Delta-26,77\end{array}$ \\
\hline КСО, мл & $\begin{array}{c}146,6 \pm \\
3,29\end{array}$ & $\begin{array}{c}126,27 \pm \\
3,31 \\
\text { p1* } \\
\Delta-13,87\end{array}$ & $\begin{array}{c}108,93 \pm \\
3,59 \\
\mathrm{p} 1 *, \mathrm{p} 2 * \\
\Delta-25,78\end{array}$ & $\begin{array}{c}148,73 \pm \\
2,96\end{array}$ & $\begin{array}{c}99,80 \pm \\
3,14 \\
\text { p1* } \\
\Delta-32,95\end{array}$ & $\begin{array}{c}92,67 \pm \\
2,38 \\
\mathrm{p} 1 *, \mathrm{p} 2 * \\
\Delta-37,72\end{array}$ & $\begin{array}{l}3 \pm \\
9\end{array}$ & $\begin{array}{c}112,47 \pm \\
4,59 \\
\text { p1* } \\
\Delta-23,03\end{array}$ & $\begin{array}{r}100 \\
4, \\
\mathrm{p} 1 * \\
\Delta-3\end{array}$ & $\begin{array}{l}149,27 \pm \\
3,13\end{array}$ & $\begin{array}{r}91, \\
4, \\
\mathrm{p} \\
\Delta-3\end{array}$ & $\begin{array}{l}80 \pm \\
14 \\
\text { p2* } \\
5,29\end{array}$ \\
\hline КДР, см & $\begin{array}{c}6,83 \pm \\
0,21\end{array}$ & $\begin{array}{c}6,33 \pm \\
0,13 \\
\mathrm{p} 1 * \\
\Delta-7,32\end{array}$ & $\begin{array}{c}6,13 \pm \\
0,11 \\
\mathrm{p} 1 *, \mathrm{p} 2 * \\
\Delta-10,25\end{array}$ & $\begin{array}{c}6,89 \pm \\
0,17\end{array}$ & $\begin{array}{c}6,14 \pm \\
0,12 \\
\text { p1* } \\
\Delta-10,89\end{array}$ & $\begin{array}{c}5,93 \pm \\
0,19 \\
\mathrm{p}^{*}, \mathrm{p} 2 * \\
\Delta-13,93\end{array}$ & $\begin{array}{r}6,8 \\
0,\end{array}$ & $\begin{array}{c}6,24 \pm \\
0,07 \\
\mathrm{p} 1 * \\
\Delta 9,17\end{array}$ & $\begin{array}{c}6,00 \pm \\
0,11 \\
\mathrm{p} 1^{*}, \mathrm{p} 2 * \\
\Delta-12,66\end{array}$ & $\begin{array}{c}6,71 \pm \\
0,22\end{array}$ & $\begin{array}{r}6,0 \\
0, \\
\mathrm{p} \\
\Delta-1\end{array}$ & $\begin{array}{l}4 \pm \\
18 \\
\text { p2* } \\
997\end{array}$ \\
\hline $\mathrm{KCP}, \mathrm{c}$ & 0 , & $\begin{array}{c}5,15 \pm \\
0,11 \\
\mathrm{p} 1 * \\
\Delta-6,87\end{array}$ & $\begin{array}{c}4,83 \pm \\
013 \\
\mathrm{p} 1 *, \mathrm{p} 2 * \\
\Delta-12,66\end{array}$ & $\begin{array}{c}5,49 \pm \\
0,14\end{array}$ & $\begin{array}{r}4,6 \\
0,1 \\
\mathrm{p} 1 \\
\Delta-1\end{array}$ & $\begin{array}{c}4,47 \pm \\
0,15 \\
\mathrm{p}^{*}, \mathrm{p} 2 * \\
\Delta-18,58\end{array}$ & & $\begin{array}{c}4,89 \pm \\
0,16 \\
\text { p1* } \\
\Delta 12,37 \\
\end{array}$ & $\begin{array}{c}4,66 \pm \\
0,13 \\
\mathrm{p} 1^{*}, \mathrm{p} 2 * \\
\Delta-16,49\end{array}$ & $\begin{array}{c}5,39 \pm \\
0,13\end{array}$ & $\begin{array}{r}4, \\
0, \\
p \\
\Delta-1\end{array}$ & $\begin{array}{l}6 \pm \\
13 \\
\text { p2* } \\
0,96\end{array}$ \\
\hline $\begin{array}{c}\text { TМШПс, } \\
\text { см }\end{array}$ & 0,10 & $\begin{array}{c}1,31 \pm \\
0,08 \\
\text { p1* } \\
\Delta-7,09\end{array}$ & $\begin{array}{c}1,25 \pm \\
0,09 \\
\mathrm{p} 1 *, \mathrm{p} 2 * \\
\Delta-11,35\end{array}$ & $\begin{array}{c}1,38 \pm \\
0,07\end{array}$ & $\begin{array}{l}0,03 \\
\mathrm{p} 1^{*} \\
\Delta-\end{array}$ & $\begin{array}{c}1,22 \pm \\
0,06 \\
\mathrm{p} 1^{*}, \mathrm{p} 2 * \\
\Delta-\end{array}$ & & $\begin{array}{c}1,25 \pm \\
0,03 \\
\mathrm{p} 1 * \\
\Delta-11,35\end{array}$ & $\begin{array}{c}1,22 \pm \\
0,02 \\
\mathrm{p} 1^{*}, \mathrm{p} 2 * \\
\Delta-13,47\end{array}$ & $\begin{array}{c}1,41 \pm \\
0,08\end{array}$ & $\begin{array}{r}1,2 \\
0, \\
\mathrm{p} \\
\Delta-1\end{array}$ & $\begin{array}{c}1,15 \pm \\
0,03 \\
\mathrm{p}^{*}, \mathrm{p} 2^{*} \\
\Delta-18,44\end{array}$ \\
\hline $\begin{array}{c}\mathrm{MШ \Pi} \\
\mathrm{cm}\end{array}$ & 0,10 & $\begin{array}{c}1,11 \pm \\
0,06 \\
\mathrm{p} 1 * \\
\Delta-11,2\end{array}$ & $\begin{array}{c}1,05 \pm \\
0,07 \\
\mathrm{p} 1^{*}, \mathrm{p} 2 * \\
\Delta-16,00\end{array}$ & $\begin{array}{c}1,27 \pm \\
0,09\end{array}$ & $\begin{array}{c}1,10 \pm \\
0,09 \\
\mathrm{p} 1 * \\
\Delta-\end{array}$ & $\begin{array}{c}1,02 \pm \\
0,06 \\
\mathrm{p} 1^{*}, \mathrm{p} 2 * \\
\Delta-\end{array}$ & & $\begin{array}{c}1,06 \pm \\
0,03 \\
\text { p1* } \\
\Delta-13,82\end{array}$ & $\begin{array}{c}1,02 \pm \\
0,03 \\
\mathrm{p} 1^{*}, \mathrm{p} 2 * \\
\Delta-17,07\end{array}$ & $\begin{array}{c}1,25 \pm \\
0,09\end{array}$ & $\begin{array}{r}1,0 \\
0, \\
\mathrm{p} \\
\Delta-1\end{array}$ & $\begin{array}{c}0,95 \pm \\
0,03 \\
\mathrm{p}^{*}, \mathrm{p} 2 * \\
\Delta-24,00\end{array}$ \\
\hline $\begin{array}{c}\text { СЛШ } \\
\text { см }\end{array}$ & 0,09 & $\begin{array}{c}1,25 \pm \\
0,06 \\
\mathrm{p} 1 * \\
\Delta-12,59\end{array}$ & $\begin{array}{c}1,19 \pm \\
0,08 \\
\mathrm{p} 1^{*}, \mathrm{p} 2 * \\
\Delta-16,78\end{array}$ & $\begin{array}{c}1,41 \pm \\
0,09\end{array}$ & $\begin{array}{c}1,37 \pm \\
0,02 \\
\mathrm{p} 1^{* *} \\
\Delta-\end{array}$ & $\begin{array}{c}1,34 \pm \\
0,03 \\
\mathrm{p} 1^{*}, \mathrm{p} 2^{*} \\
\Delta-\end{array}$ & 0 & $\begin{array}{c}1,20 \pm \\
0,02 \\
\mathrm{p} 1^{*} \\
\Delta-16,67\end{array}$ & $\begin{array}{c}1,15 \pm \\
0,03 \\
\mathrm{p} 1^{*}, \mathrm{p} 2 * \\
\Delta-20,14\end{array}$ & $\begin{array}{c}1,45 \pm \\
0,06\end{array}$ & $\begin{array}{l} \pm \\
5 \\
86\end{array}$ & $\begin{array}{c}1,16 \pm \\
0,04 \\
\mathrm{p} 1^{*}, \mathrm{p} 2^{*} \\
\Delta-20,00\end{array}$ \\
\hline $\begin{array}{c}\text { СЛШ д, } \\
\text { см }\end{array}$ & $\begin{array}{c}1,22 \pm \\
0,09\end{array}$ & $\begin{array}{r}1,1 \\
0,0 \\
\mathrm{p} 1 \\
\Delta-9\end{array}$ & $\begin{array}{r}0,9 \\
0, \\
\mathrm{p} 1^{*}, \\
\Delta-1\end{array}$ & $\begin{array}{c}1,23 \pm \\
0,07\end{array}$ & $\begin{array}{r}1,1 \\
0,0 \\
\mathrm{p} 1 \\
\Delta\end{array}$ & $\begin{array}{c}1,14 \pm \\
0,03 \\
\mathrm{p} 1^{*}, \mathrm{p} 2^{*} \\
\Delta-\end{array}$ & & $\begin{array}{c}1,00 \pm \\
0,03 \\
\text { p1* } \\
\Delta-19,35\end{array}$ & $\begin{array}{r}0,9 \\
0, \\
\mathrm{p}^{*}, \\
\Delta-2\end{array}$ & $\begin{array}{c}1,27 \pm \\
0,11\end{array}$ & $\begin{array}{l} \pm \\
7 \\
96\end{array}$ & $\begin{array}{c}0,94 \pm \\
0,03 \\
\mathrm{p} 1^{*}, \mathrm{p} 2^{*} \\
\Delta-25,98\end{array}$ \\
\hline$\Phi B, \%$ & $\begin{array}{r}39,0 \\
1,7\end{array}$ & $\begin{array}{c}40,87 \pm \\
1,61 \\
\mathrm{p} 1 *\end{array}$ & $\begin{array}{c}42,4 \pm \\
1,60 \\
\mathrm{p} 1 *, \mathrm{p} 2 * \\
\Delta+7,07\end{array}$ & $\begin{array}{c}39,40 \pm \\
1,96\end{array}$ & $\begin{array}{r}46, \\
1,1 \\
\mathrm{p} 1 \\
\Delta+1^{\prime}\end{array}$ & $\begin{array}{c}47,67 \pm \\
1,23 \\
\mathrm{p} 1^{*}, \mathrm{p} 2 * \\
\Delta+20,99\end{array}$ & $\begin{array}{r}38, \\
4,\end{array}$ & $\begin{array}{c}43,00 \pm \\
2,85 \\
\mathrm{p} 1 * \\
\Delta+12,45\end{array}$ & $\begin{array}{r}45, \\
2, \\
\mathrm{p}^{*}, \\
\Delta+1\end{array}$ & $\begin{array}{c}40,00 \pm \\
1,60\end{array}$ & $\begin{array}{r}49, \\
1, \\
\mathrm{p}\end{array}$ & $\begin{array}{c}53,07 \pm \\
1,75 \\
\mathrm{p} 1^{*}, \mathrm{p} 2 * \\
\Delta+32,68\end{array}$ \\
\hline $\mathrm{yc}$ & $\begin{array}{c}91,80 \pm \\
3,00\end{array}$ & $\begin{array}{c}77,73 \pm \\
2,99 \\
\text { p1* }\end{array}$ & $\begin{array}{c}81,53 \pm \\
2,64 \\
\mathrm{p} 1 *, \mathrm{p} 2 * \\
\Delta-11,19\end{array}$ & $\begin{array}{c}92,40 \pm \\
1,84\end{array}$ & $\begin{array}{c}89,60 \pm \\
1,92 \\
\text { p1* } \\
\Delta-3,03\end{array}$ & $\begin{array}{c}82,40 \pm \\
2,13 \\
\mathrm{p} 1^{*}, \mathrm{p} 2 * \\
\Delta-10,82\end{array}$ & $\begin{array}{l}p_{ \pm} \\
2\end{array}$ & $\begin{array}{c}85,13 \pm \\
2,75 \\
\mathrm{p} 1 *\end{array}$ & $\begin{array}{c}80,80 \pm \\
2,14 \\
\mathrm{p} 1^{*}, \mathrm{p} 2 *\end{array}$ & $\begin{array}{c}92,80 \pm \\
1,15\end{array}$ & 0 & $\begin{array}{c}93,40 \pm \\
1,92 \\
\mathrm{p} 1 * *, \mathrm{p} 2 * \\
\Delta-0,65\end{array}$ \\
\hline $\begin{array}{c}\text { Тиск в } \\
\text { легеневій } \\
\text { артерії, } \\
\text { мм.рт.ст. }\end{array}$ & 3 & $\begin{array}{r}34,4 \\
3,0 \\
\text { p1 }\end{array}$ & $\begin{array}{c}32,13 \pm \\
2,85 \\
\mathrm{p} 1 *, \mathrm{p} 2 * \\
\Delta-14,39\end{array}$ & $\begin{array}{c}38,23 \pm \\
4,44\end{array}$ & $\begin{array}{r}32,2 \\
2,9 \\
\text { p } 1\end{array}$ & $\begin{array}{c}29,20 \pm \\
3,86 \\
\mathrm{p} 1^{*}, \mathrm{p} 2 * \\
\Delta-23,62\end{array}$ & 4 & $\begin{array}{c}33,47 \pm \\
1,85 \\
\text { p1* } \\
\Delta-12,47\end{array}$ & $\begin{array}{c}31,40 \pm \\
1,45 \\
\mathrm{p} 1^{*}, \mathrm{p} 2 * \\
\Delta-17,89\end{array}$ & $\begin{array}{c}39,53 \pm \\
3,37\end{array}$ & $\begin{array}{r}28, \\
2, \\
\text { p }\end{array}$ & $\begin{array}{c}25,60 \pm \\
3,18 \\
\mathrm{p} 1 * *, \mathrm{p} 2 * \\
\Delta-35,24\end{array}$ \\
\hline$\underset{\Gamma / \mathrm{M}^{2}}{\text { IMМЛ, }}$ & 3,35 & $\begin{array}{c}170,60 \pm \\
3,02 \\
\mathrm{p} 1 * \\
\Delta-28,22\end{array}$ & $\begin{array}{c}150,33 \pm \\
2,78 \\
\mathrm{p} 1 *, \mathrm{p} 2 * \\
\Delta-36,75\end{array}$ & \begin{tabular}{|c|}
$237,65 \pm$ \\
2,19
\end{tabular} & $\begin{array}{c}140,73 \pm \\
3,26 \\
\text { p1* } \\
\Delta-40,78\end{array}$ & $\begin{array}{c}135,27 \pm \\
2,76 \\
\mathrm{p} 1^{*}, \mathrm{p} 2 * \\
\Delta-43,08\end{array}$ & $\begin{array}{c}234,87 \pm \\
3,34\end{array}$ & $\begin{array}{c}155,53 \pm \\
3,85 \\
\text { p1* } \\
\Delta-33,78\end{array}$ & $\begin{array}{c}142,13 \pm 3 \\
64 \\
\mathrm{p} 1 *, \mathrm{p} 2 * \\
\Delta-39,49\end{array}$ & $\begin{array}{c}36,80= \\
37\end{array}$ & $\begin{array}{c}139,00 \\
\pm 2,51 \\
\mathrm{p} 1 *\end{array}$ & $\begin{array}{c}132,07 \pm 2,4 \\
9 \\
\mathrm{p} 1 * *, \mathrm{p} 2 * \\
\Delta-44,23\end{array}$ \\
\hline ММЛШ, г & $\begin{array}{c}416,67 \pm \\
3,98\end{array}$ & $\begin{array}{c}315,20 \pm \\
3,78 \\
\text { p1* } \\
\Delta-24,35\end{array}$ & $\begin{array}{c}278,07 \pm \\
3,88 \\
\mathrm{p} 1 *, \mathrm{p} 2 * \\
\Delta-33,26\end{array}$ & $\begin{array}{c}414,07 \pm \\
3,51\end{array}$ & $\begin{array}{c}259,33 \pm \\
2,58 \\
\text { p1* } \\
\Delta-37,37\end{array}$ & $\begin{array}{c}229,53 \pm \\
4,31 \\
\mathrm{p} 1^{*}, \mathrm{p} 2 * \\
\Delta-44,57\end{array}$ & $\begin{array}{c}413,33 \pm \\
3,27\end{array}$ & $\begin{array}{c}280,87 \pm \\
3,23 \\
\mathrm{p} 1 * \\
\Delta-32,05\end{array}$ & $\begin{array}{c}249,73 \pm 3 \\
15 \\
\mathrm{p} 1 *, \mathrm{p} 2 * \\
\Delta-39,58\end{array}$ & $\begin{array}{c}414,53 \pm \\
2,95\end{array}$ & $\begin{array}{c}255,27 \\
\pm 2,71 \\
\mathrm{p} 1 * \\
\Delta-38,42\end{array}$ & $\begin{array}{c}224,60 \\
\pm 3,29 \\
\mathrm{p} 1^{*}, \mathrm{p} 2 * \\
\Delta-45,82\end{array}$ \\
\hline $\begin{array}{c}\text { «Стінка- } \\
\text { радіус», } \\
\text { у.од }\end{array}$ & $\begin{array}{c}0,36 \pm \\
0,02\end{array}$ & $\begin{array}{c}0,35 \pm \\
0,02 \\
\mathrm{p} 1^{*} \\
\Delta-2,78\end{array}$ & $\begin{array}{c}0,32 \pm \\
0,05 \\
\mathrm{p} 1 *, \mathrm{p} 2 * \\
\Delta-11,11\end{array}$ & $\begin{array}{c}0,35 \pm \\
0,03\end{array}$ & $\begin{array}{c}0,38 \pm \\
0,02 \\
\text { p1* } \\
\Delta-11,43\end{array}$ & $\begin{array}{c}0,39 \pm \\
0,02 \\
\mathrm{p} 1^{*}, \mathrm{p} 2 * \\
\Delta-8,57\end{array}$ & $\begin{array}{c}0,36 \pm \\
0,02\end{array}$ & $\begin{array}{c}0,38 \pm \\
0,02 \\
\text { p1* } \\
\Delta+5,56\end{array}$ & $\begin{array}{c}0,31 \pm \\
0,03 \\
\mathrm{p} 1^{*}, \mathrm{p} 2 * \\
\Delta-13,89\end{array}$ & $\begin{array}{c}0,36 \pm \\
0,02\end{array}$ & $\begin{array}{c}0,35 \pm \\
0,03 \\
\mathrm{p}^{* *} \\
\Delta-2,78\end{array}$ & $\begin{array}{c}0,33 \pm \\
0,03 \\
\mathrm{p} 1^{*}, \mathrm{p} 2 * \\
\Delta-8,33\end{array}$ \\
\hline
\end{tabular}

Примітка. Вірогідність різниці р1 - порівняно з показниками до лікування, p2 - порівняно 3 показниками після 1 місяця лікування, * - p<0,05, ** - p1>0,05; $\Delta$ - приріст, або зменшення (-) показника в процесі лікування у відсотках до величин до початку лікування. 
Таблиця 2

Динаміка показників гемодинаміка у хворих з перенесеним не $Q$ інфарктом міокарда та декомпенсованою серцевою недостатністю

\begin{tabular}{|c|c|c|c|c|c|c|c|c|c|c|c|c|}
\hline \multirow{2}{*}{ Група $/$} & \multicolumn{3}{|c|}{$\begin{array}{c}\text { Стандартне лікування } \\
\text { (n=15) }\end{array}$} & \multicolumn{3}{|c|}{$\begin{array}{l}\text { Стандартне лікування + } \\
\text { янтарна кислота }(\mathrm{n}=15)\end{array}$} & \multicolumn{3}{|c|}{$\begin{array}{c}\text { Стандартне лікування + } \\
\text { препарати аргініну }(\mathrm{n}=15)\end{array}$} & \multicolumn{3}{|c|}{$\begin{array}{c}\text { Стандартне лікування + } \\
\text { янтарна кислота }+ \text { препа- } \\
\text { рати аргініну }(n=15)\end{array}$} \\
\hline & $\begin{array}{c}\text { До } \\
\text { ліку- } \\
\text { вання }\end{array}$ & 1 мiс. & 2 мiс. & $\begin{array}{c}\text { До ліку- } \\
\text { вання }\end{array}$ & 1 мiс. & 2 мiс. & $\begin{array}{c}\text { До ліку- } \\
\text { вання }\end{array}$ & 1 мic. & 2 мiс. & $\begin{array}{c}\text { До ліку- } \\
\text { вання }\end{array}$ & 1 мic. & 2 мiс. \\
\hline $\begin{array}{l}\text { КДО, } \\
\text { мл }\end{array}$ & $\begin{array}{c}235,87 \pm \\
9,42\end{array}$ & $\begin{array}{c}200,73 \pm \\
7,70 \\
\mathrm{p} 1^{*} \\
\Delta-14,97\end{array}$ & $\begin{array}{c}184,87 \pm \\
8,85 \\
\mathrm{p} 1^{*}, \mathrm{p} 2 * \\
\Delta-21,62\end{array}$ & $\begin{array}{c}239,93 \pm \\
5,73\end{array}$ & $\begin{array}{c}186,67 \pm \\
4,30 \\
\mathrm{p} 1 * \\
\Delta-22,27\end{array}$ & $\begin{array}{c}172,80 \pm \\
4,06 \\
\mathrm{p} 1^{*}, \mathrm{p} 2 * \\
\Delta-27,98\end{array}$ & $\begin{array}{c}238,40 \pm \\
6,39\end{array}$ & $\begin{array}{c}194,73 \pm \\
4,68 \\
\mathrm{p} 1 * \\
\Delta-18,32\end{array}$ & $\begin{array}{c}182,40 \pm \\
5,70 \\
\mathrm{p} 1^{*}, \mathrm{p} 2 * \\
\Delta-23,49\end{array}$ & $\begin{array}{c}237,67 \pm \\
6,41\end{array}$ & $\begin{array}{c}170,93 \pm \\
4,25 \\
\text { p1* } \\
\Delta-28,08\end{array}$ & $\begin{array}{c}160,87 \pm \\
4,98 \\
\mathrm{p} 1^{*}, \mathrm{p} 2 * \\
\Delta-32,31\end{array}$ \\
\hline $\begin{array}{c}\mathrm{KCO}, \\
\text { мл }\end{array}$ & $\begin{array}{c}148,00 \pm \\
3,25\end{array}$ & $\begin{array}{c}123,20 \pm \\
5,71 \\
\mathrm{p} 1 * \\
\Delta-16,76\end{array}$ & $\begin{array}{c}107,87 \pm \\
5,84 \\
\mathrm{p} 1^{*}, \mathrm{p} 2 * \\
\Delta-27,11\end{array}$ & $\begin{array}{c}147,13 \pm \\
1,64\end{array}$ & $\begin{array}{c}100,67 \pm \\
4,43 \\
\mathrm{p} 1 * \\
\Delta-31,58\end{array}$ & $\begin{array}{c}88,73 \pm \\
3,75 \\
\mathrm{p} 1^{*}, \mathrm{p} 2^{*} \\
\Delta-39,69\end{array}$ & $\begin{array}{c}147,07 \pm \\
2,09\end{array}$ & $\begin{array}{c}105,67 \pm \\
3,74 \\
\mathrm{p} 1 * \\
\Delta-28,15\end{array}$ & $\begin{array}{c}91,80 \pm \\
2,48 \\
\mathrm{p} 1^{*}, \mathrm{p} 2 * \\
\Delta-37,58\end{array}$ & $\begin{array}{c}147,07 \pm \\
1,58\end{array}$ & $\begin{array}{c}87,73 \pm \\
2,81 \\
\mathrm{p} 1^{*} \\
\Delta-40,35\end{array}$ & $\begin{array}{c}78,20 \pm \\
2,24 \\
\mathrm{p} 1^{*}, \mathrm{p} 2 * \\
\Delta-46,83\end{array}$ \\
\hline $\begin{array}{c}\text { КДР, } \\
\mathrm{cm}\end{array}$ & $\begin{array}{c}6,89 \pm \\
0,19\end{array}$ & $\begin{array}{c}6,29 \pm \\
0,04 \\
\mathrm{p} 1 * \\
\Delta-8,71 \\
\end{array}$ & $\begin{array}{c}6,07 \pm \\
0,23 \\
\mathrm{p} 1 *, \mathrm{p} 2 * \\
\Delta-11,90 \\
\end{array}$ & $\begin{array}{c}6,71 \pm \\
0,21\end{array}$ & $\begin{array}{c}6,10 \pm \\
0,28 \\
\text { p1* } \\
\Delta-9,09\end{array}$ & $\begin{array}{c}5,88 \pm \\
0,21 \\
\mathrm{p}^{*}, \mathrm{p} 2 * \\
\Delta-12,37\end{array}$ & $\begin{array}{c}6,66 \pm \\
0,17\end{array}$ & $\begin{array}{c}6,20 \pm \\
0,08 \\
\text { p1* } \\
\Delta-6,91 \\
\end{array}$ & $\begin{array}{c}6,03 \pm \\
0,07 \\
\mathrm{p} 1^{*}, \mathrm{p} 2 * \\
\Delta-9,46\end{array}$ & $\begin{array}{c}6,65 \pm \\
0,11\end{array}$ & $\begin{array}{c}5,98 \pm \\
0,18 \\
\text { p1* } \\
\Delta-10,08 \\
\end{array}$ & $\begin{array}{c}5,69 \pm \\
0,09 \\
\mathrm{p}^{*}, \mathrm{p} 2 * \\
\Delta-14,44 \\
\end{array}$ \\
\hline КСР, см & $\begin{array}{c}5,59 \pm \\
0,16\end{array}$ & $\begin{array}{c}5,12 \pm \\
0,11 \\
\mathrm{p} 1^{*} \\
\Delta-8,41\end{array}$ & $\begin{array}{c}4,81 \pm \\
0,13 \\
\mathrm{p}^{*}, \mathrm{p} 2 * \\
\Delta-13,95\end{array}$ & $\begin{array}{c}5,49 \pm \\
0,11\end{array}$ & $\begin{array}{c}4,65 \pm \\
0,13 \\
\mathrm{p} 1 * \\
\Delta-15,30\end{array}$ & $\begin{array}{c}4,41 \pm \\
0,15 \\
\mathrm{p} 1^{*}, \mathrm{p} 2 * \\
\Delta-19,67\end{array}$ & $\begin{array}{c}5,49 \pm \\
0,12\end{array}$ & $\begin{array}{c}4,75 \pm \\
0,41 \\
\mathrm{p} 1 * \\
\Delta-13,48\end{array}$ & $\begin{array}{c}4,58 \pm \\
0,40 \\
\mathrm{p} 1^{*}, \mathrm{p} 2 * \\
\Delta-16,58\end{array}$ & $\begin{array}{c}5,51 \pm \\
0,13\end{array}$ & $\begin{array}{c}4,38 \pm \\
0,17 \\
\text { p1* } \\
\Delta-20,51\end{array}$ & $\begin{array}{c}4,19 \pm \\
0,19 \\
\mathrm{p}^{*}, \mathrm{p} 2 * \\
\Delta-23,96\end{array}$ \\
\hline $\begin{array}{l}\text { ТМШПс, } \\
\text { см }\end{array}$ & $\begin{array}{c}1,39 \pm \\
0,07\end{array}$ & $\begin{array}{c}1,32 \pm \\
0,04 \\
\mathrm{p} 1^{*} \\
\Delta-5,04\end{array}$ & $\begin{array}{c}1,22 \pm \\
0,05 \\
\mathrm{p}^{*}, \mathrm{p} 2 * \\
\Delta-12,23\end{array}$ & $\begin{array}{c}1,41 \pm \\
0,08\end{array}$ & $\begin{array}{c}1,21 \pm \\
0,06 \\
\mathrm{p} 1 * \\
\Delta-14,18\end{array}$ & $\begin{array}{c}1,15 \pm \\
0,07 \\
\mathrm{p}^{*}, \mathrm{p} 2 * \\
\Delta-18,44\end{array}$ & $\begin{array}{c}1,40 \pm \\
0,06\end{array}$ & $\begin{array}{c}1,23 \pm \\
0,06 \\
\mathrm{p} 1 * \\
\Delta-12,14\end{array}$ & $\begin{array}{c}1,18 \pm \\
0,03 \\
\mathrm{p} 1^{*}, \mathrm{p} 2 * \\
\Delta-15,71\end{array}$ & $\begin{array}{c}1,42 \pm \\
0,09\end{array}$ & $\begin{array}{c}1,26 \pm \\
0,04 \\
\mathrm{p} 1^{*} \\
\Delta-11,27\end{array}$ & $\begin{array}{c}1,19 \pm \\
0,03 \\
\mathrm{p}^{*}, \mathrm{p} 2 * \\
\Delta-16,26\end{array}$ \\
\hline $\begin{array}{c}\text { ТМШПд, } \\
\text { см }\end{array}$ & $\begin{array}{c}1,29 \pm \\
0,12\end{array}$ & $\begin{array}{c}1,20 \pm \\
0,08 \\
\mathrm{p} 1^{*} \\
\Delta-6,98\end{array}$ & $\begin{array}{c}1,12 \pm \\
0,05 \\
\mathrm{p}^{*}, \mathrm{p} 2 * \\
\Delta-13,18\end{array}$ & $\begin{array}{c}1,22 \pm \\
0,13\end{array}$ & $\begin{array}{c}1,02 \pm \\
0,07 \\
\mathrm{p} 1 * \\
\Delta-16,39\end{array}$ & $\begin{array}{c}0,95 \pm \\
0,06 \\
\mathrm{p}^{*}, \mathrm{p} 2^{*} \\
\Delta-22,13\end{array}$ & $\begin{array}{c}1,23 \pm \\
0,13\end{array}$ & $\begin{array}{c}1,03 \pm \\
0,08 \\
\mathrm{p} 1 * \\
\Delta-16,26\end{array}$ & $\begin{array}{c}0,98 \pm \\
0,05 \\
\mathrm{p} 1^{*}, \mathrm{p} 2 * \\
\Delta-20,33\end{array}$ & $\begin{array}{c}1,22 \pm \\
0,10\end{array}$ & $\begin{array}{c}1,06 \pm \\
0,02 \\
\mathrm{p} 1^{*} \\
\Delta-13,11\end{array}$ & $\begin{array}{c}0,99 \pm \\
0,07 \\
\mathrm{p}^{*}, \mathrm{p} 2 * \\
\Delta-18,85\end{array}$ \\
\hline $\begin{array}{c}\text { ТЗСЛШ с, } \\
\text { см }\end{array}$ & $\begin{array}{c}1,41 \pm \\
0,08\end{array}$ & $\begin{array}{c}1,22 \pm \\
0,05 \\
\mathrm{p} 1 * \\
\Delta-13,48\end{array}$ & $\begin{array}{c}1,18 \pm \\
0,04 \\
\mathrm{p} 1^{*}, \mathrm{p} 2 * \\
\Delta-16,31\end{array}$ & $\begin{array}{c}1,41 \pm \\
0,07\end{array}$ & $\begin{array}{c}1,20 \pm \\
0,04 \\
\mathrm{p} 1 * \\
\Delta-14,89 \\
\end{array}$ & $\begin{array}{c}1,13 \pm \\
0,07 \\
\mathrm{p} 1 *, \mathrm{p} 2 * \\
\Delta-19,86\end{array}$ & $\begin{array}{c}1,41 \pm \\
0,09\end{array}$ & $\begin{array}{c}1,25 \pm \\
0,04 \\
\mathrm{p} 1 * \\
\Delta-11,35 \\
\end{array}$ & $\begin{array}{c}1,22 \pm \\
0,05 \\
\mathrm{p} 1^{*}, \mathrm{p} 2 * \\
\Delta-13,48\end{array}$ & $\begin{array}{c}1,43 \pm \\
0,08\end{array}$ & $\begin{array}{c}1,19 \pm \\
0,02 \\
\text { p1* } \\
\Delta-16,78\end{array}$ & $\begin{array}{c}1,12 \pm \\
0,03 \\
\mathrm{p}^{*}, \mathrm{p} 2 * \\
\Delta-21,68 \\
\end{array}$ \\
\hline $\begin{array}{c}\text { ТЗСЛШ д, } \\
\text { см }\end{array}$ & $\begin{array}{c}1,21 \pm \\
0,06\end{array}$ & $\begin{array}{c}1,02 \pm \\
0,04 \\
\mathrm{p} 1^{*} \\
\Delta-15,70\end{array}$ & $\begin{array}{c}0,98 \pm \\
0,08 \\
\mathrm{p} 1^{*}, \mathrm{p} 2 * * \\
\Delta-19,01\end{array}$ & $\begin{array}{c}1,19 \pm \\
0,05\end{array}$ & $\begin{array}{c}1,1 \pm \\
0,08 \\
\mathrm{p} 1^{*} \\
\Delta-7,56\end{array}$ & $\begin{array}{c}0,94 \pm \\
0,03 \\
\mathrm{p}^{*}, \mathrm{p}^{*} \\
\Delta-11,86\end{array}$ & $\begin{array}{c}1,21 \pm \\
0,04\end{array}$ & $\begin{array}{c}1,06 \pm \\
0,07 \\
\text { p1* } \\
\Delta-12,45\end{array}$ & $\begin{array}{c}1,01 \pm \\
0,04 \\
\mathrm{p} 1^{*}, \mathrm{p} 2 * \\
\Delta-16,53\end{array}$ & $\begin{array}{c}1,25 \pm \\
0,07\end{array}$ & $\begin{array}{c}1,01 \pm \\
0,04 \\
\mathrm{p}^{*} \\
\Delta-19,2\end{array}$ & $\begin{array}{c}0,92 \pm \\
0,03 \\
\mathrm{p} 1^{*}, \mathrm{p} 2 * \\
\Delta-26,40\end{array}$ \\
\hline $\begin{array}{c}\Phi B, \\
\%\end{array}$ & $\begin{array}{c}40,20 \pm \\
1,90\end{array}$ & $\begin{array}{c}41,60 \pm \\
1,72 \\
\mathrm{p} 1 * \\
\Delta+3,48\end{array}$ & $\begin{array}{c}43,00 \pm \\
1,89 \\
\mathrm{p} 1 *, \mathrm{p} 2 * \\
\Delta+6,97\end{array}$ & $\begin{array}{c}39,47 \pm \\
2,88\end{array}$ & $\begin{array}{c}46,27 \pm \\
2,60 \\
\mathrm{p} 1 * \\
\Delta+17,23\end{array}$ & $\begin{array}{c}48,27 \pm \\
3,31 \\
\mathrm{p} 1 *, \mathrm{p} 2 * \\
\Delta+22,34\end{array}$ & $\begin{array}{c}39,67 \pm \\
1,23\end{array}$ & $\begin{array}{c}44,00 \pm \\
2,80 \\
\mathrm{p} 1 * \\
\Delta+10,92\end{array}$ & $\begin{array}{c}48,73 \pm \\
2,94 \\
\mathrm{p} 1^{*}, \mathrm{p} 2 * \\
\Delta+22,84\end{array}$ & $\begin{array}{c}39,67 \pm \\
2,66\end{array}$ & $\begin{array}{c}50,00 \pm \\
2,42 \\
\mathrm{p} 1 * \\
\Delta+26,04\end{array}$ & $\begin{array}{c}53,40 \pm \\
2,16 \\
\mathrm{p} 1^{*}, \mathrm{p} 2 * \\
\Delta+34,61\end{array}$ \\
\hline $\begin{array}{l}\text { УО, } \\
\text { мл }\end{array}$ & $\begin{array}{c}92,47 \pm \\
1,68\end{array}$ & $\begin{array}{c}77,20 \pm \\
2,11 \\
\mathrm{p} 1 * \\
\Delta-16,51 \\
\end{array}$ & $\begin{array}{c}74,80 \pm \\
2,34 \\
\mathrm{p} 1 *, \mathrm{p} 2 * \\
\Delta-19,11\end{array}$ & $\begin{array}{c}91,67 \pm \\
1,54\end{array}$ & $\begin{array}{c}86,00 \pm \\
3,55 \\
\mathrm{p} 1 * \\
\Delta-6,19 \\
\end{array}$ & $\begin{array}{c}82,60 \pm \\
2,29 \\
\mathrm{p} 1^{*}, \mathrm{p} 2 * \\
\Delta-9,89\end{array}$ & $\begin{array}{c}93,07 \pm \\
1,33\end{array}$ & $\begin{array}{c}88,40 \pm \\
2,09 \\
\mathrm{p} 1 * \\
\Delta-5,02\end{array}$ & $\begin{array}{c}90,80 \pm \\
2,31 \\
\mathrm{p} 1^{*}, \mathrm{p} 2 * \\
\Delta-2,44\end{array}$ & $\begin{array}{c}92,60 \pm \\
1,40\end{array}$ & $\begin{array}{c}84,47 \pm \\
1,61 \\
\text { p1* } \\
\Delta-8,78\end{array}$ & $\begin{array}{c}81,87 \pm \\
1,92 \\
\mathrm{p} 1 *, \mathrm{p} 2 * \\
\Delta-11,59\end{array}$ \\
\hline $\begin{array}{c}\text { Тиск в } \\
\text { легеневій } \\
\text { артерії, } \\
\text { мм.рт.ст. }\end{array}$ & $\begin{array}{c}34,72 \pm \\
3,10\end{array}$ & $\begin{array}{c}32,67 \pm \\
2,06 \\
\mathrm{p} 1^{*} \\
\Delta-5,90\end{array}$ & $\begin{array}{c}31,13 \pm \\
2,01 \\
\mathrm{p} 1 *, \mathrm{p} 2 * \\
\Delta-10,34\end{array}$ & $\begin{array}{c}38,91 \pm \\
3,79\end{array}$ & $\begin{array}{c}30,93 \pm \\
2,69 \\
\mathrm{p} 1 * \\
\Delta-20,51\end{array}$ & $\begin{array}{c}28,13 \pm \\
3,23 \\
\mathrm{p}^{*}, \mathrm{p} 2^{*} \\
\Delta-27,70\end{array}$ & $\begin{array}{c}37,73 \pm \\
4,09\end{array}$ & $\begin{array}{c}32,40 \pm \\
2,89 \\
\mathrm{p} 1 * \\
\Delta-14,13\end{array}$ & $\begin{array}{c}30,07 \pm \\
3,17 \\
\mathrm{p} 1^{*}, \mathrm{p} 2 * \\
\Delta-20,30\end{array}$ & $\begin{array}{c}38,13 \pm \\
4,11\end{array}$ & $\begin{array}{c}27,60 \pm \\
1,55 \\
\text { p1* } \\
\Delta-27,62\end{array}$ & $\begin{array}{c}24,53 \pm \\
2,13 \\
\mathrm{p} 1^{*}, \mathrm{p} 2 * \\
\Delta-35,67\end{array}$ \\
\hline $\begin{array}{c}\text { ІММЛШ, } \\
\Gamma / \mathrm{M}^{2}\end{array}$ & $\begin{array}{c}236,87 \pm \\
2,72\end{array}$ & $\begin{array}{c}169,47 \pm \\
5,48 \\
\mathrm{p} 1 * \\
\Delta-28,45\end{array}$ & $\begin{array}{c}148,87 \pm \\
5,11 \\
\mathrm{p} 1^{*}, \mathrm{p} 2 * \\
\Delta-37,15\end{array}$ & $\begin{array}{c}237,60 \pm \\
2,61\end{array}$ & $\begin{array}{c}152,53 \pm \\
3,64 \\
\mathrm{p} 1 * \\
\Delta-35,80\end{array}$ & $\begin{array}{c}122,87 \pm \\
3,54 \\
\mathrm{p} 1^{*}, \mathrm{p} 2 * \\
\Delta-48,29\end{array}$ & $\begin{array}{c}236,80 \pm \\
2,76\end{array}$ & $\begin{array}{c}153,00 \pm \\
4,58 \\
\mathrm{p} 1 * \\
\Delta-35,39\end{array}$ & $\begin{array}{c}137,13 \pm \\
4,42 \\
\mathrm{p} 1^{*}, \mathrm{p} 2 * \\
\Delta-42,09\end{array}$ & $\begin{array}{c}238,27 \pm \\
3,13\end{array}$ & $\begin{array}{c}141,47 \pm \\
3,41 \\
\text { p1* } \\
\Delta-40,63\end{array}$ & $\begin{array}{c}118,47 \pm \\
2,50 \\
\mathrm{p} 1^{*}, \mathrm{p} 2 * \\
\Delta-50,28\end{array}$ \\
\hline $\begin{array}{c}\text { ММЛШ, } \\
\Gamma\end{array}$ & $\begin{array}{c}415,67 \pm \\
3,68\end{array}$ & $\begin{array}{c}313,13 \pm \\
5,85 \\
\mathrm{p} 1 * \\
\Delta-24,67\end{array}$ & $\begin{array}{c}275,93 \pm \\
5,76 \\
\mathrm{p}^{*}, \mathrm{p} 2^{*} \\
\Delta-33,62\end{array}$ & $\begin{array}{c}415,47 \pm \\
2,53\end{array}$ & $\begin{array}{c}281,40 \pm \\
3,72 \\
\text { p1* } \\
\Delta-32,27\end{array}$ & $\begin{array}{c}229,07 \pm \\
2,91 \\
\mathrm{p}^{*}, \mathrm{p} 2 * \\
\Delta-44,86\end{array}$ & $\begin{array}{c}414,60 \pm \\
3,83\end{array}$ & $\begin{array}{c}284,07 \pm \\
4,40 \\
\text { p1* } \\
\Delta-31,48\end{array}$ & $\begin{array}{c}253,73 \pm \\
4,74 \\
\mathrm{p} 1^{*}, \mathrm{p} 2 * \\
\Delta-38,80\end{array}$ & $\begin{array}{c}412,53 \pm \\
2,59\end{array}$ & $\begin{array}{c}263,20 \pm \\
4,21 \\
\text { p1* } \\
\Delta-36,27\end{array}$ & $\begin{array}{c}218,53 \pm \\
3,34 \\
\mathrm{p} 1^{*}, \mathrm{p} 2 * \\
\Delta-47,03\end{array}$ \\
\hline $\begin{array}{c}\text { «Стінка- } \\
\text { радіус», } \\
\text { у.од }\end{array}$ & $\begin{array}{c}0,36 \pm \\
0,02\end{array}$ & $\begin{array}{c}0,33 \pm \\
0,01 \\
\mathrm{p} 1 * \\
\Delta-8,33\end{array}$ & $\begin{array}{c}0,31 \pm \\
0,01 \\
\mathrm{p} 1^{*}, \mathrm{p} 2 * \\
\Delta-13,89\end{array}$ & $\begin{array}{c}0,36 \pm \\
0,02\end{array}$ & $\begin{array}{c}0,34 \pm \\
0,02 \\
\mathrm{p} 1 * \\
\Delta-5,56\end{array}$ & $\begin{array}{c}0,33 \pm \\
0,01 \\
\mathrm{p} 1^{*}, \mathrm{p} 2 * * \\
\Delta-8,33 \\
\end{array}$ & $\begin{array}{c}0,35 \pm \\
0,02\end{array}$ & $\begin{array}{c}0,34 \pm \\
0,02 \\
\mathrm{p} 1 * * \\
\Delta-2,86\end{array}$ & $\begin{array}{c}0,32 \pm \\
0,02 \\
\mathrm{p} 1^{*}, \mathrm{p} 2 * \\
\Delta-8,57\end{array}$ & $\begin{array}{c}0,35 \pm \\
0,02\end{array}$ & $\begin{array}{c}0,35 \pm \\
0,02 \\
\mathrm{p} 1 * * \\
\Delta-0,00\end{array}$ & $\begin{array}{c}0,33 \pm \\
0,01 \\
\mathrm{p} 1^{*}, \mathrm{p} 2^{*} \\
\Delta-5,71\end{array}$ \\
\hline
\end{tabular}

Примітка. Вірогідність різниці p1 - порівняно з показниками до лікування, p2 - порівняно з показниками після 1 місяця лікування, * - p $<0,05, * *-p 1>0,05 ; \Delta-$ приріст, або зменшення (-) показника в процесі лікування у відсотках до величин до початку лікування. 
Так, ТЗСЛШд у групі хворих, які отримували стандартну терапію, становила $(1,29 \pm 0,12)$ см до лікування, $(1,20 \pm 0,08)$ см ( $<0,05)$ після 1 місяця лікування та $(1,12 \pm 0,05)$ см $(\mathrm{p}<0,05)$ після 2 місяців терапії; у групі хворих, які отримували янтарну кислоту, $(1,22 \pm 0,13)$ см, $(1,02 \pm 0,07) \quad$ см та $(0,95 \pm 0,06) \quad \mathrm{cm}$ $(\mathrm{p}<0,05)$ відповідно; у групі хворих, які отримували препарати аргініну, $-(1,23 \pm 0,13) \mathrm{cm},(1,03 \pm 0,08)$ см та $(0,98 \pm 0,05)$ см $(\mathrm{p}<0,05)$ відповідно та у групі хворих, які поряд із стандартною терапією отримували поєднання янтарної кислоти та препаратів аргініну, $(1,22 \pm 0,10) \mathrm{cm},(1,06 \pm 0,02) \mathrm{cm},(0,99 \pm 0,07) \mathrm{cm}(\mathrm{p}<0,05)$ відповідно

Констатовано і достовірне зниження ММЛШ, особливо у четвертій групі хворих, де використовували поєднання запропонованих препаратів. ММЛШ у цій групі до лікування становила $(412,53 \pm 2,59)$ г, після 1 місяця терапії $(263,20 \pm 4,21)$ г $(\mathrm{p}<0,05)$ та 2 місяців - $(218,53 \pm 3,34)$ г $(\mathrm{p}<0,05)$. Показник «стінкарадіус» у групі хворих, які отримували стандартну терапію, становив $(0,35 \pm 0,02)$ у.од. до лікування, $(0,33 \pm 0,01)$ у.од. $(\mathrm{p}<0,05)$ після 1 місяця лікування та $(0,31 \pm 0,01)$ у.од. $(\mathrm{p}<0,05)$ після 2 місяців терапії; у групі хворих, які отримували янтарну кислоту, $(0,36 \pm 0,02)$ у.од., $(0,34 \pm 0,02)$ у.од., $(0,33 \pm 0,01)$ у.од. $(\mathrm{p}<0,05)$ відповідно; у групі хворих, які отримували препарати аргініну, - $(0,35 \pm 0,02)$ у.од., $(0,34 \pm 0,02)$ у.од., $(0,32 \pm 0,02)$ у.од. $(\mathrm{p}<0,05)$ відповідно та у групі хворих, які поряд із стандартною терапією отримували поєднання янтарної кислоти та препаратів аргініну, - $(0,35 \pm 0,02)$ у.од., $(0,35 \pm 0,02)$ у.од., $(0,33 \pm 0,01)$ у.од. відповідно.

\section{Висновки:}

1. Застосування у хворих після перенесеного IM, ускладненого декомпенсованою $\mathrm{CH}$, янтарної кислоти та препаратів аргініну дозволяе забезпечити корекцію ряду клініко-патогенетичних ланок захворювання, що, в цілому, сприяє покращенню метричних та об'ємних показників серця.

2. Результати дослідження показали, що включення до лікувального комплексу янтарної кислоти та препаратів аргініну дозволяє значно посилити ефективність стандартної терапії, що проявляється, певною мірою, у стриманні первинного та вторинного ремоделювання ЛШ та більш швидкого відновлення його геометрії та скоротливості. Тому застосування поряд зі стандартною терапією цих препаратів $є$ доцільним для такого контингенту хворих.

\section{References:}

1. Kalynin RE, Suchkov IA i dr. Effektivnost L-arginina v lechenii aterosklerosa arteriy nygnych konechnostey I profilaktyke restenoza zony rekonstrukzii. Praktychna angiologiya. 2015; 1(68):25-27. Available from: https://cyberleninka.ru/article/n/effektivnost-l-arginina-vlechenii-ateroskleroza-arteriy-nizhnih-konechnostey-iprofilaktike-restenoza-zony-rekonstruktsii.

2. Melnykova YuS, Makarova TP. Endotelialna dysfunktsiya kak tsentralnoe zveno patogeneza chronicheskych bolezney Kazanskyj medytsynskyi zhurnal. 2015; 96(4):659-665. Available from: https://cyberleninka.ru/article/n/endotelialnaya- disfunktsiya-kak-tsentralnoe-zveno-patogenezahronicheskih-bolezney.

3. Novykov VE, Levchenkova OS. Novyye napravleniya poiska lekarstvennych sredstv $\mathrm{s}$ angygipoksycheskoy aktyvnostyu i misheni ich deystviy. Eksperymentalnaya i klinicheskaya farmakologiya. 2013; 76(5):37-47. Available from: http://ekf.folium.ru/index.php/ekf/article/view/73.

4. Tashchuk VK, Ivanchuk VK, Tashchuk MV, Polyanska OS, Amelina TM, Makoviychuk OM ta in. Kilkisna otsinka elektrokardiogramy $\mathrm{v}$ porivnnyanni efektyvnosti kardioprotektsii pry gostromu infarcti miokarda. Bukovynskyi medychnyi visnyk. 2017; 2(82):94-99. Available from: http://e-bmv.bsmu.edu.ua/article/view/24130737.XXI.2.82.1.2017.20.

5. Shachmardanova SA, Gulevskaja ON, Chamanashvili YaA, Zelenskaya AV, Nefedov LF, GalenkoYaroshevskyi PA. Preperaty yantarnoi b fuvarovoi kyslot kak sredstva profylaktyky i terapii razlichnych zabolevaniy. Zhurnal fundamentalnoy medytsyny i biology. 2016; 3:16-30. Available from: https://cyberleninka.ru/article/n/preparaty-yantarnoy-ifumarovoy-kislot-kak-sredstva-profilaktiki-i-terapiirazlichnyh-zabolevaniy.

6. Chen C, Ponnusamy M, Liu C, Gao J, Wang K, Li P (2017) MicroRNA as a therapeutic target in cardiac remodeling Biomed Res Int. 2017:2018-2023. Available from: https://www.ncbi.nlm.nih.gov/pubmed/29094041. DOI: $10.1155 / 2017 / 1278436$.

7. Gombozhapova A, Rogovskaya Y, Shurupov V, Rebenkova M, Kzhyshkowska J, Popov SV at all. Macrophage activation and polarization in post-infarction cardiac remodeling J Biomed Sci. 2017; 7; 24(1):13. Availablefrom:

https://www.ncbi.nlm.nih.gov/pmc/articles/PMC5297120 /. DOI: $10.1186 / \mathrm{s} 12929-017-0322-3$.

8. Katz AM, Rolett EL. Heart failure: when form fails to follow function Eur Heart J. 2016; 37:449-454. Available from: https://www.ncbi.nlm.nih.gov/pubmed/26497163. DOI:10.1093/eurheartj/ehv548.

9. Lüscher TF. Heart failure and left ventricular remodeling in HFrEF and HFpEF Eur Heart J. 2018; 1; 37(5):423-4. Available from: https:/www.ncbi.nlm.nih.gov/pubmed/26834206.

DOI:10.1093/eurheartj/ehw004.

10. Liu L, Wu J, Kennedy DJ. Regulation of cardiac remodeling by cardiac na+/K+-ATPase isoforms. Front Physiol; 2018; 7. P.382. Available from: https://www.ncbi.nlm.nih.gov/pubmed/27667975. DOI: 10.3389/fphys.2016.00382.

11. Marc C, Corneliu AI, Corneliu I, Ober CD, Hamorodean C,Serban B at all (2018) Prerevascularization coronary wedge pressure as marker of adverse long-term left ventricular remodelling in patients with acute ST-segment elevation mtocardial infarction Sci Rep. 2018; 8. P.1897. Available from: https:/www.ncbi.nlm.nih.gov/pubmed/29382891. DOI: 10.1038/s41598-018-20276-6.

12. McCarroll CS, He W. Runx1 deficiency protects against adverse cardiac remodeling after myocardial infarction Circulation. 2018; 137:57-70. Available from: https:/www.ncbi.nlm.nih.gov/pubmed/29030345. DOI: 10.1161/CIRCULATIONAHA.117.028911. 
13. Mele D, Nardozza M, Ferrari R. Left ventricular ejection fraction and heart failure: an additional marriage? Eur J Heart Fail. 2018; 20:427-430. Available from: https://www.ncbi.nlm.nih.gov/pubmed/29314500. DOI: 0.002/ejhf.07.

14. Shen S, Jiang H, Bei Y, Xiao J, Li X. Long noncoding RNAs in cardiac remodeling Cell Physiol Biochem. 2017; 41:1830-1837. Available from: https://www.ncbi.nlm.nih.gov/pubmed/28376483. DOI: 10.1159/000471913.

15. Smiseth OA, Torp H, Opdahl A, Haugaa KH, Urheim S. Myocardial strain imaging: how useful is it in clinical decision making? Eur Heart J 2016; 37:441-447. Available from:

https://www.ncbi.nlm.nih.gov/pubmed/26508168. DOI: doi.org/10.1093/eurheartj/ehv529.

16. Teerlink JR, Metra M, Filippatos GS, Davison BA, Bartunek J, Terzic A at all. Benefit of cardiopoietic mesenchymal stem cell therapy on left ventricular remodelling: results from the Congestive Heart Failure Cardiopoietic Regenerative Therapy (CHART-1) study. Eur J Heart Fail. 2017; 19(11):1520-1529. Available from: https://www.ncbi.nlm.nih.gov/pubmed/28560782. DOI: 10.1002/ejhf.898.

17. Wu QQ, Xiao Y, Yuan Y, Ma ZG, Liao HH, Liu C, Zhu JX, Yang Z, Deng W, Tang QZ. Mechanisms contributing to cardiac remodelling Clin Sci (Lond). 2017; 131(18):2319-2345. Available from: https://www.ncbi.nlm.nih.gov/pubmed/28842527. DOI: 10.1042/CS20171167.

\section{УДК $616.007 .61+616.12+616.12-008.46+616.127-$ $005.8+615.03$ \\ ДИНАМИКА ПОКАЗАТЕЛЕЙ ГИПЕРТРОФИИ И РЕМОДЕЛИРОВАНИЯ ЛЕВОГО ЖЕЛУДОЧ- КА У БОЛЬНЫХ С ДЕКОМПЕНСИРОВАННОЙ СЕРДЕЧНОЙ НЕДОСТАТОЧНОСТЬЮ В ПОСТИНФАРКТНОМ ПЕРИОДЕ ПОСЛЕ ПРОВЕДЕНОГО ВОССТАНОВИТЕЛЬНОГО ЛЕЧЕНИЯ}

\section{И.П. Вакалюк, Х.В. Левандовска}

Ивано-Франковский национальный медицинский университет, кафедра внутренней медицины №2 и медсестринства, г. Ивано-Франковск, Украина, ORCID ID: 0000-0002-4430-6816, ORCID ID: 0000-0003-3259-7940, e-mail:levandovska87@ukr.net

Резюме. Цель: определить основные показатели гипертрофии и ремоделирования левого желудочка у больных после перенесенного инфаркта миокарда, осложненного декомпенсированной сердечной недостаточностью и динамику их изменений на фоне проводимого лечения янтарной кислотой и препаратами аргинина.

Материалы и методы исследования. Обследовано 120 больных с диагнозом Q-QS и не-Q инфаркт миокарда, в которых зафиксирована декомпенсированная ХCH II А-Б стадии по классификации
В. Х. Василенко и Н. Д. Стражеско III-IV ФК (по NYHA). Исследованы группы были однородными по возрасту, полу, тяжести течения заболевания, длительности постинфарктного периода, наличию клинических проявлений декомпенсации. Всем пациентам проведено эхокардиографическое обследование на аппарате «CARIS PLUS» («Biomedice», Италия). Были оценены показатели ремоделирования и гипертрофии миокарда.

Результаты исследования и их обсуждение. В течение 2 месяцев лечения больных с перенесенным Q ИМ было констатировано значительное улучшение гемодинамических показателей функционирования ЛЖ и его сократительной функции. Такие показатели, как КДО, КСО, КДР, КСР, ММЛШ и ИММЛЖ значительно снизились во всех обследованных пациентов, особенно у тех, которые наряду со стандартной терапией получали комбинацию исследуемых препаратов. Анализируя показатели Эхо КГ у больных с перенесенным не-Q ИМ, установлено достоверное снижение метрических и объемных показателей ЛЖ.

Выводы. Применение у больных после перенесенного ИМ, осложненного декомпенсированной $\mathrm{CH}$, янтарной кислоты и препаратов аргинина позволяет обеспечить улучшение метрических и объемных показателей сердца, а также в определенной степени сдержать первичное и вторичное ремоделирования ЛЖ. Использование наряду с базовой терапией данных препаратов целесообразно для данного контингента больных.

Ключевые слова: ремоделирование миокарда, декомпенсированная сердечная недостаточность, инфаркт миокарда, янтарная кислота, препараты аргинина.

\section{UDC $616.007 .61+616.12+616.12-008.46+616.127-$ $005.8+615.03$ \\ DYNAMICS OF HYPERTROPHY INDICATORS AND LEFT VENTRICULAR REMODELING IN PATIENTS WITH DECOMPANSATED HEART FAILURE IN THE POST-INFARCTION PERIOD AFTER REMEDIAL TREATMENT}

I.P. Vakaliuk, K.V. Levandovska

Ivano- Frankivsk National Medical University, Department of Internal Medicine №2 and Nursing, Ivano-Frankivsk, Ukraine, ORCID ID: 0000-0002-4430-6816, ORCID ID: 0000-0003-3259-7940, e-mail:levandovska87@ukr.net

Abstract. The aim of the study was to assess the main indicators of hypertrophy and remodeling of the left ventricle in patients after myocardial infarction, complicated by decompensated heart failure and to determine the dynamics of their changes in the background of treatment with succinic acid and preparations of arginine. 
Materials and Methods. There were examined 120 patients with Q-QS wave and non-Q wave myocardial infarction; stage II A-B decompensated chronic heart failure according to the classification proposed by Vasylenko V. Kh. and Strazhesko M. D., the New York Heart Association functional class III-IV. Study groups were homogenous by age, gender, disease severity, duration of the post-infarction period, clinical signs of decompensation, that served as a basis for inclusion of the patients in the study. All patients have an echocardiographic examination on the CARIS PLUS device (Biomedice, Italy). In all the patients, the indicators of remodeling LV such as end-diastolic dimension (EDD), LV end-diastolic volume (EDV), LV interventricular septal thickness (IVST) in systole and diastole, LV posterior wall thickness (PVT) in systole and diastole, LV myocardial mass (MM), LV myocardial mass index (MMI), LV radius to wall thickness ratio were assessed. The patients with Q-QS myocardial infarction (60 individuals) and with non $Q$ myocardial infarction (60 patients) were divided into 4 groups depending on the treatment methods.

Results of the research and their discussion. During 2 months of treatment with transmitted myocardial infarction, there were significant improvements in hemodynamics parameters of the left ventricle function and its contractive ability. Such indicators, as EDD, ESD, EDV, ESV, IVST in systole and diastole, LV PVT in systole and diastole, LV MM, LV MMI, LV radius to wall thickness ratio were significantly lower in all of the examined patients, especially those who, with standard therapy, received a combination of succinic acid and preparations of arginine Analyzing echo-cardiological indicators in patients after non-Q MI, complicated with decompensated HF have been installed a significant increase of metric and volume values of LV after 1 and 2 months of treatment. Thus, there was a significant decrease of LV MM, especially in the fourth group of patients, where the combination of proposed drugs were used. LV MM in this group before treatment was 412.53 $\pm 2.59 \mathrm{~g}$ before treatment, after 1 month of treatment $(263.20 \pm 4.21) \mathrm{g}(\mathrm{p}<0.05)$ and 2 months $(218.53 \pm 3.34)$ $\mathrm{g}(\mathrm{p}<0.05)$. There was also a positive dynamics of increasing of EF LV and decreasing pulmonary arterial pressure in patients after Q and non-Q MI and decompensated HF.

Conclusions. Application in patients after a myocardial infarction, complicated by decompensated heart failure, succinic acid and arginine preparations allows to improve the metric and volume parameters of the heart. The results of the study have shown that the use of a combination of standard therapy and succinic acid and preparations of arginine can significantly enhance the effectiveness of the first, which, to some extent, manifests itself, in the restraint of primary and secondary remodeling of the left ventricle. That is why the application, along with basic therapy, of these drugs is appropriate for this contingent of patients.

Keywords: myocardial remodeling, decompensated heart failure, myocardial infarction, succinic acid, preparations of arginine.

Стаття надійшла в редакцію 14.08.2019 р. 